\title{
The Eastern Lower Tagus Valley Fault Zone in central Portugal: Active faulting in a low-deformation region within a major river environment
}

\author{
Carolina Canora ${ }^{\mathrm{a}}$, Susana P. Vilanova ${ }^{\mathrm{a}, *}$, Glenda M. Besana-Ostman ${ }^{\mathrm{a}, 1}$, João Carvalho ${ }^{\mathrm{b}}$, \\ Sandra Heleno ${ }^{a}$, Joao Fonseca ${ }^{a}$ \\ a Centro de Recursos Naturais e Ambiente (CERENA), Instituto Superior Técnico (IST), Universidade de Lisboa, Av. Rovisco Pais, 1., 1049-001 Lisbon, Portugal \\ b Laboratório Nacional de Energia e Geologia, Estrada da Portela, Bairro do Zambujal Apartado 7586-Alfragide, 2610-999 Amadora, Portugal
}

\section{A R T I C L E I N F O}

Article history:

Received 6 January 2015

Received in revised form 13 August 2015

Accepted 15 August 2015

Available online $\mathrm{xxxx}$

\section{Keywords:}

Active faulting

Paleoseismology

Intraplate region

Reflection seismology

Iberian Peninsula

\begin{abstract}
A B S T R A C T
Active faulting in the Lower Tagus Valley, Central Portugal, poses a significant seismic hazard that is not well understood. Although the area has been affected by damaging earthquakes during historical times, only recently has definitive evidence of Quaternary surface faulting been found along the western side of the Tagus River. The location, geometry and kinematics of active faults along the eastern side of the Tagus valley have not been previously studied. We present the first results of mapping and paleoseismic analysis of the eastern strand of the Lower Tagus Valley Fault Zone (LTVFZ). Geomorphological, paleoseismological, and seismic reflection studies indicate that the Eastern LTVFZ is a left-lateral strike-slip fault. The detailed mapping of geomorphic features and studies in two paleoseismic trenches show that surface fault rupture has occurred at least six times during the past $10 \mathrm{ka}$. The river offsets indicate a minimum slip rate on the order of $0.14-0.24 \mathrm{~mm} / \mathrm{yr}$ for the fault zone. Fault trace mapping, geomorphic analysis, and paleoseismic studies suggest a maximum magnitude for the Eastern LTVFZ of $\mathrm{M}_{\mathrm{w}} \sim 7.3$ with a recurrence interval for surface ruptures $\sim 1.7 \mathrm{ka}$. At least two events occurred after $1175 \pm 95 \mathrm{cal}$ yr BP. Single-event displacements are unlikely to be resolved in the paleoseismic trenches, thus our observations most probably represent the minimum number of events identified in the trenches.
\end{abstract}

(C) 2015 Published by Elsevier B.V.

\section{Introduction}

Active faulting within major river valleys poses a seismic hazard which, given the concentration of both infrastructure and population typically located in such environments, is often associated with a significant seismic risk.

The Lower Tagus Valley (LTV) is an NNE-SSE trending valley located in the southwestern region of the Iberian Peninsula. It includes part of the Lisbon Greater Area - the most developed and densely populated region of Portugal. According to the most recent studies, the LTV displays the highest levels of both seismic hazard (e.g., Vilanova and Fonseca, 2007; Giardini et al., 2014) and seismic risk (Silva et al., 2014) in Portugal.

Several destructive earthquakes have affected the valley during historical times. Some of the earthquakes that caused serious damage and many casualties along the valley have been associated with the Lower Tagus Valley Fault Zone (LTVFZ). However, both the location and the kinematics of the LTVFZ remained elusive and controversial for decades: the fault has been considered a left-lateral fault by Fonseca (1989) and

\footnotetext{
* Corresponding author. Tel.: + 351218419214

E-mail address: susana.vilanova@tecnico.ulisboa.pt (S.P. Vilanova).

1 Present address: Seismology, Geomorphology and Geophysics Group, Bureau of Reclamation, US Department of the Interior, Denver, Colorado 80225, United States.
}

Fonseca and Long (1991), a thrust fault by Cabral (1993), and a normal fault by Ribeiro et al. (1996). Recently, Besana-Ostman et al. (2012) provided the first compelling evidence of active left-lateral faulting along the western side of the Tagus River, herein called the Western LTVFZ. The current paper extends the results of Besana-Ostman et al. (2012) to the eastern side of the Tagus River and aims to shed some light into the nature of the fault zone and its characteristics.

We describe the deformational style and paleoseismic history of the newly mapped eastern fault traces, herein called the Eastern LTVFZ. This study involved 1) geomorphic mapping of active fault scarps and offset landforms; 2) paleoseismic trenching across fault scarps in order to establish the timing of past surface fault displacements; and 3) acquisition of P-wave seismic reflection data to study the fault geometry at depth. Both fault traces and data from the trenches were used to evaluate possible rupture scenarios and earthquake magnitude and recurrence. We have also analyzed offsets observed along the drainage network in order to obtain a minimum slip rate for the fault. Our study contributes new data that are essential for the evaluation of seismic hazard in the region.

\section{Overview of the regional tectonic setting}

The Iberian Peninsula is located within the Eurasian plate, close to its southern boundary with the African plate (Fig. 1a). While the central 